BSU International Journal of Humanitites and Social Science

Available Online: http://buijhs.journals.ekb.eg/

Online ISSN: 2314-8810 Print ISSN: 2314-8802

BSU International Journal of Humanities and Social Sciences

BSU. HUM.SOC (BIJHSS)

Vol.2

Issue2 (2020)

Published by Beni-Suef University 
BSU Intemational Jounna of Humanities and Social Science

Available Online: http://buijhs.journals.ekb.eg/

Online ISSN: 2314-8810 Print ISSN: 2314-8802

Online-ISSN: 2314-8810

Print-ISSN: 2314-8802

https://buijhs.journals.ekb.eg/ 


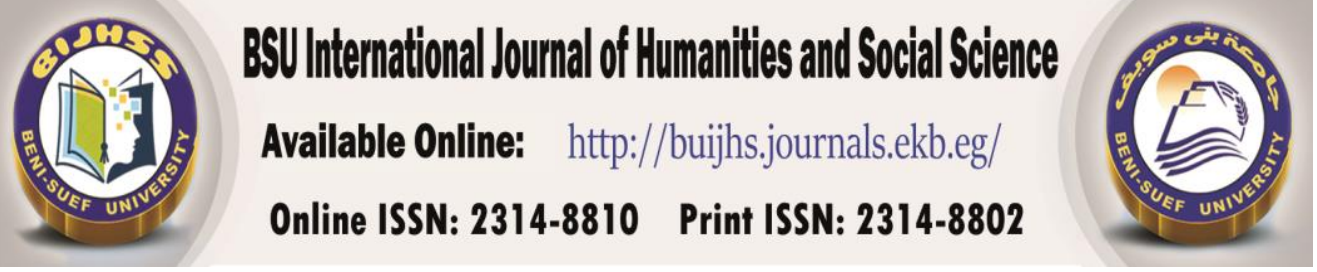

\section{Board of Directors}

Prof. Mansour Hassan

\section{President of Beni-Suef University}

\section{Chairman of the Board of Directors}

\section{Prof. Fatma Hassan}

Vice University President for Higher Studies and Research، Beni-Suef University

\section{Prof. Maha Ahmed Mohamed}

\section{Editor-in-chief}

Associate Professor of Information Science, Faculty of Arts, Beni-Suef University

\section{Editorial Board}

Prof. Dr. Ashraf Khaled

Member

Vice University President for Education and Students Affairs

Prof. Dr. Badr Nabih

Member

Vice University President for Community Service and Environmental Development

Prof. Dr. Hesham Azmi

Member

Professor of Library and Information Science, Faculty of Arts, Cairo University.

Prof. Dr. Mustafa Alfakharany

Member

Professor an der Germanistikabteilung und Vize-Dekan der Sprache und . bersetzungsfakult t der Uni Alazahr in Kairo, . gypten.

Prof. Dr. Ali Gamal Al-Din Ezzat

Member

Professor of linguistics, faculty of Education, Ain Shams University

Prof. Heba Mostafa Mohamed Mostafa

Deputy Editor-in-chief

Assistant Professor of Curriculum \& Instruction English Language, Faculty of Faculty of Education, Beni-Suef University

Dr. Ashraf Samir Mohamed Ahmed

Managing Editor

Lecturer of Linguistics The German Department / Faculty of Al Alsun. Beni-Suef University

\section{A. Mohamed Rabie Abdelzaher Abdelmotalb}

Technical Editor

Assistant Lecturer. Faculty of Arts, Department of Geography and Geographic Information Systems
A. Taha Mohamed Taha Hassan
page designer

Assistant Lecturer, Department of Information Science, Faculty of Arts, Beni-Suef University 


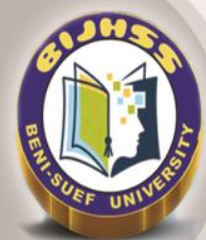

BSU International Jounnal of Humanitites and Social Science

Available Online: http://buijhs.journals.ekb.eg/

Online ISSN: 2314-8810 Print ISSN: 2314-8802

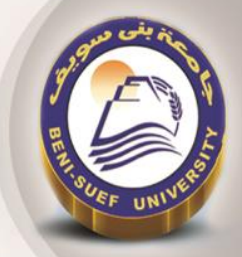

\section{Editorial Board}

\section{International Advisory Board}

ANGELIKI PANAGOPOULOU

(Greece)

Lecturer, Department of History and Archaeology, University of Ioannina, Greece Athanassios Sakellariadis

(Greece)

University of Ioannina, Greece, Department of Philology, Phil. of Science, Phil. of Language

Ayda Shakib

(USA)

Professor of Financial and Commercial Studies, Faculty of Commerce,

BLOCH Pascale

(Paris)

School of Law, Paris 13 University, Sorbonne Paris Cité, law, exceptional position

Choudhary Zahid Javid

(Pakistan)

Assistant Professor of Applied Linguistics, Taif University, Saudi Arabia

Eric M. Uslaner

(Maryland)

Professor at the Department of Government and Politics University of Maryland

Jean-Sylvestre Bergé

( Paris)

University of Jean Moulin Lyon 3 (France), law

Kevin J. Miller

Nebraska-Lincoln, USA, Education

Kirstie Blai

Stirling, UK, English Studies

MACDONALD, Malcolm Newsome

Professor in Applied Linguistics, Centre for Applied Linguistics,University of Warwick, UK

\section{Maria-Luiza Oancea}

(Romania)

Bucharest, Romania, Foreign Languages and Literatures, Classical Philology 
BSU International Journal of Humantities and Social Science

Available Online: http://buijhs.journals.ekb.eg/

Online ISSN: 2314-8810 Print ISSN: 2314-8802

Matthias Grünke

(German)

Pool of international short-term experts University of Cologne

Mihai-Dan Chițoiu

(Romania)

Alexandru Ioan Cuza University, Romania, Department of Philosophy, Byzantine Philosophy Ancient Philosophy

Sauoma BouJaoude

(Lebanon)

American University of Beirut, Center for Teaching and Learning \& Science and Math Education Center, Education

Segatti Ermis

(Italy)

Turin, Italy, interregional theological faculty, Religious Studies

Shawky Salem

(Canada)

Professor of Library and Information Science, Faculty of Arts,

Taso G. Lagos

(USA)

University of Washington, Jackson School of International Studies, Political Economy, Cinema Studies and History

TOMÁS SILVA SÁNCHEZ

(Spain)

Department of Classical Philology Spain

Wilhelm Danca

(Romania)

philosopher and Romanian theologian, corresponding member of the Romanian Academy 


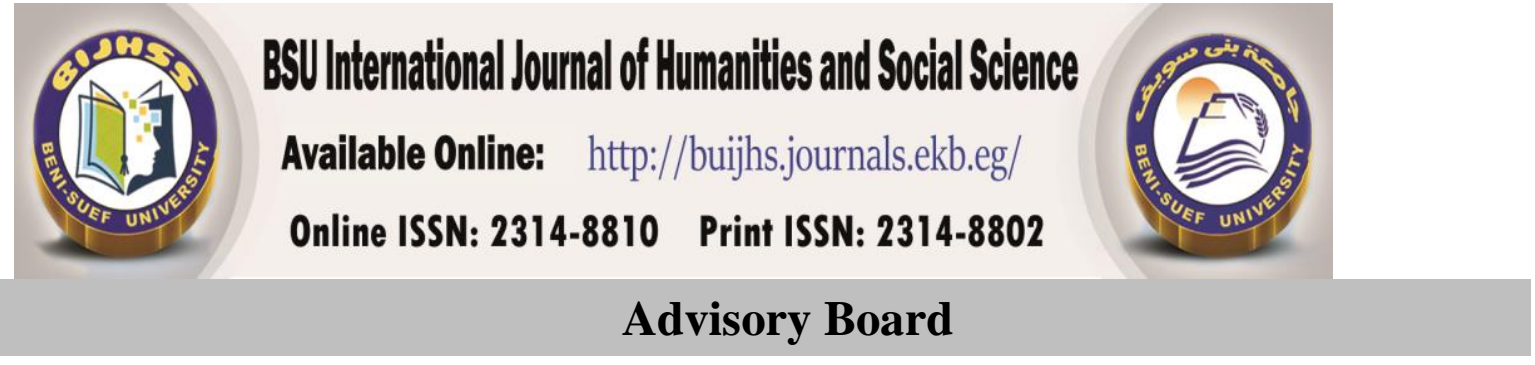

\section{Prof. Dr. Ahmed Hashad}

Professor of Spanish Language. Al Azhar university

\section{Prof. Dr. Ahmed Abdel Ellalah El Sheemi}

Professor of English Literature and Translation . Beni-Suef University

\section{Prof. Dr. Ahmed Kamal safwat Al Alfy}

Professor of German Department, Faculty of Al-sun, Ain Shams University, Cairo, Egypt

\section{Prof. Dr. Ali Attia Massoud Hassan}

Professor of International Money and Finance.Beni-Suef University

Prof. Dr. Esmat Hussien Nassar

Professor of Philosophy, Faculty of Arts, Cairo University

\section{Prof. Dr. Hisham Abdelhamid Tohami}

Professor of Psychology.Beni-Suef University

\section{Prof. Dr. Hossam Lotfy}

Professor of Civil Law .faculty of Commerce. Beni-Suef University

\section{Prof. Dr. Hossam El-Din Mohamed Kamel El Ahwaney}

Professor of Civil Law, Faculty of Law. Mansoura University

\section{Prof. Dr. Ibrahim Abdullah}

Professor of German Language.Faculty of Al Alsun, Beni-Suef University

\section{Prof. Dr. Kawthar Abdel Fattah Al Abgy}

Professor of Accounting, faculty of Commerce. Beni-Suef University

\section{Prof. Dr. Mohy El-Din Mohamed Abdel-Hadi Mutawa}

Professor of Greek and Latin language and literature. Head of Faculty of $\mathrm{Al}$ Alsun .Beni-Suef University 


\section{BSU International Journal of Humantities and Social Science \\ Available Online: http://buijhs.journals.ekb.eg/ \\ Online ISSN: 2314-8810 Print ISSN: 2314-8802 \\ $\underline{\text { Aims and Scope }}$}

Beni-Suef University Journal of Humanities and Social Sciences (BIJHSS) is an international, open access and peerreviewed journal. It aspires to publish high quality original research articles, review articles, short communication and case reports, which focus on at least one of the topics of social science and humanities and not have been published or considered for publication elsewhere

Beni-Suef University Journal of Humanities and Social Sciences (BIJHSS) is a Semi - annual periodical that publishes original articles and review articles in areas of publishes original research papers, reviews, case studies, surveys and technical notes on social science and humanities, Particularly, Philosophy, Education, Anthropology, Sociology, Psychology, and Political Science. 